\title{
Party and Leader Effects in Parliamentary Elections: Towards a Reassessment
}

\author{
Diego Garzia \\ European University Institute
}

\begin{abstract}
Social-psychological models of voting behavior systematically downsize the relevance of party leader evaluations by conceiving them as mere consequences of causally prior partisan attachments. However, the validity of this interpretation depends heavily on the effectively exogenous status of party identification. Empirical research shows that the assumed exogeneity of partisanship is, at best, doubtful. In such context, single-equation models of voting are likely to provide seriously biased estimates. By employing the proper econometric procedures (instrumental variable estimation) and the most appropriate data sources to address causality issues (panel data) this study provides strong support in favor of the personalization hypothesis.
\end{abstract}

Keywords: electoral behavior, endogeneity, party identification, personalization of politics, research methods

Acknowledgments: I am indebted to Michael Lewis-Beck and Paolo Bellucci for their precious comments on earlier drafts of this paper. I would also like to thank Martin Coward and the anonymous reviewers of POLITICS for their critical remarks and suggestions. A preliminary version of this paper has been presented at the $34^{\text {th }}$ Annual Scientific Meeting of the International Society of Political Psychology held at Istanbul Bilgi University in July 2011. I thank the panel chair, Tereza Capelos, and all the participants for the useful comments received. Of course, I remain the sole responsible for all the unavoidable the mistakes still present. 


\section{Introduction}

In the recent decades, political parties have undergone deep transformations that are at once cause and consequence of the personalization of politics (McAllister, 2007; Garzia, 2011) in established parliamentary democracies. The decline of cleavage-based voting (Franklin, Mackie, and Valen, 1992) forced class-mass parties to reshape their electoral appeal in order to extend the electoral support beyond the segment of voters to which they usually referred (Mair, Muller, and Plasser, 2004). This process of transformation into catch-all parties implies the declining role of ideology at the expense of features more appealing to the voters, such as the personality of the party leaders (Farrell and Webb, 2000). Additionally, the growth of television as major source of political information for a wide majority of Western electorates has further reinforced the political weight of individual politicians at the expense of their own parties (Mughan, 2000).

One of the most crucial consequences of personalization lies - or at least, should lie - in the increasing centrality of leaders' personality in the individual voting calculus. A widespread interpretation of contemporary voters' behavior is that they 'tend increasingly to vote for a person and no longer for a party or a platform' (Manin, 1997, p. 219). Others go even further, contending that 'election outcomes are now, more than at any time in the past, determined by voters' assessments of party leaders' (Hayes and McAllister, 1997, p. 3). However, the common wisdom that sees popular party leaders as a fundamental electoral asset for their own parties has been fiercely contested by comparative electoral research (King, 2002; Curtice and Holmberg, 2005; Karvonen, 2010; Holmberg and Oscarsson, 2011). As a common denominator, the present literature rests on the classic social-psychological framework set forth in The American Voter, in which short-term influences on voting behavior are themselves subject to 
explanation in terms of temporally and causally prior forces (Campbell et al., 1960, pp. 24-37; Thomassen, 2005, pp. 7-17). In such framework, leader evaluations stand as a sort of residual category, as they appear 'strongly mediated by such situational factors as the strength as well as the direction of partisan affiliation' (Brettschneider and Gabriel, 2002, p. 153).

The enduring validity of such an interpretation of voters' behavior rests on the strong assumption that party identification is relatively fixed and immune from shortterm forces. However, a variety of empirical works has shown that the assumed exogeneity of partisanship is, at best, doubtful (for a review, see: Marks, 1993). Voters might well like a party leader just because he is the leader of the party with which they identify. Yet the reverse might be true as well - voters could declare themselves partisans simply because of the appeal of the party's leader (Curtice and Holmberg, 2005, p. 239; Garzia, 2012). If the latter was the case, then trying to estimate the magnitude of leadership effects by controlling for party identification 'would understate the final impact of leaders' images by misattributing to party identification [...] a portion of leadership's direct effects' (Dinas, 2008, p. 508).

In this paper, I take up the task of reassessing the magnitude of leader effects in parliamentary elections. I do so by employing the necessary econometric procedures (i.e., instrumental variable estimation) to overcome the problem of reciprocal causation between voters' feelings of partisanship and their evaluation of party leaders. The following section reviews the relevant literature on leader effects and highlights its main weaknesses under a methodological point of view. Next, empirical measures are presented. The statistical analysis is performed using the data source that is best suited to address causality issues: panel data. For illustrative purposes, the analysis is performed on timely national election study data from three established parliamentary 
democracies in Western Europe: Britain, Germany, and Italy. The results are discussed in the concluding section, along with their foremost implications for the study of leader effects in democratic elections.

\section{Party identification and leader evaluations: An endogenous relationship}

In the classic Michigan model, vote choices are conceived as a function of the cumulative consequences of temporally ordered sets of factors' (Miller and Shanks, 1996, p. 192). At the heart of this model lies the notion of party identification - a longterm affective orientation to a political party, which is rooted in early socialization and based on an objective location in the social structure (Campbell et al., 1960). Due to its social-psychological nature, party identification is conceived as an unmoved mover: that is, a pre-political attitude that is nonetheless able to shape the individuals' political world-view in a way that accords with their partisan orientation (Johnston, 2006). On these bases, partisanship is thought to be cause (but not consequence) of less stable attitudes and opinions about issues and candidates.

The exogenous status of party identification, however, is far from being uncontested (Holmberg, 2007). In their seminal contribution, Page and Jones (1979) demonstrate that party loyalties 'do not function purely as fixed determinants of the vote; those loyalties can themselves be affected by attitudes toward the current candidates. Even short of major realignments, party affiliations are effects as well as causes in the electoral process' (Page and Jones, 1979, p. 1088). Regrettably, only a few analyses of leader effects have taken this conclusion into account. Some of them limit to recognize the problem of endogeneity (Crewe and King, 1994; Evans and Andersen, 2005; Dinas, 2008), while in only a bunch of cases the two-way causal link between party identification and leader/candidate evaluations is addressed empirically 
(Archer, 1987; Marks, 1993). It is an unfortunate occurrence, as without this specification 'the effects of partisanship on the vote are likely to be exaggerated' (Marks, 1993, p. 143), with leader effects substantially downsized as a result.

Indeed, virtually all the available comparative evidence of leader effects on the vote points to the key role played by party identification in orienting voters' short-term attitudes and vote choices in turn (see, most notably, the various chapters in: King, 2002; Thomassen, 2005; Aarts, Blais, and Schmitt, 2011). Despite their widespread acceptance among political sociologists and electoral researchers, however, the conclusions from these studies are potentially biased in the light of the kind of data employed as well as the specification of the empirical model. ${ }^{1}$

With respect to the first point, suffice it to say that virtually all the available evidence of party leader effects on the vote relies on cross-sectional data. However, 'as long as the data are cross-sectional, any inference about structural effects must remain weak' (Lewis-Beck, Nadeau, and Elias, 2008, p. 85). Whereas previous scholarship on leader effects had to face the lack of appropriate panel data, this restriction does not seem to apply anymore insofar good electoral panels are nowadays available in abundance. In this paper, three such data sources will be employed for illustrative purposes: the British Election Study 2009-2010, the German Longitudinal Election Study 2009, and the Italian National Election Study $2006 .^{2}$

With regard to the specification of the voting model, previous scholars' choice to control for party identification (in spite of its endogenous status) rests on the idea that 'on the one hand, if the party...factor is not controlled for, party leader effects will be seriously overestimated. On the other hand, if we control for the party variable, leader effects might be somewhat underestimated' (Holmberg and Oscarsson, 2011, p. 37). In the attempt to estimate as accurately as possible the relative effect of parties and 
leaders on the vote, our reassessment acknowledges the need to control for the party factor within the voting model (otherwise, leader effects might be seriously overestimated). In doing so, however, remedial actions must be undertaken in order not to underestimate the actual effect of leaders. The link of reciprocal causation between partisanship and leader evaluations has to be taken into account, as in such context these covariates become effectively endogenous and their estimated effects potentially biased. To overcome this problem, it is necessary to properly exogenize the offending variable (i.e., partisanship) through the construction of an instrumental variable in a two-stage process. If partisanship is correctly exogenized (that is, purified by the influence of leader evaluations) then it can be safely included in a model of voting without the risk of unjustifiably downsizing the electoral effect of leader evaluations.

\section{Empirical measures}

The dependent variable is respondents' vote choice, measured in the post-election wave of the surveys and coded as in Table 1 . The main covariates included in the analysis are respondents' partisanship (PID) and party leaders' evaluation (LEAD). In turn, PID takes the values of '-1' for identifiers with the main leftist party in each country, ' 1 ' for identifiers with the main rightist party, and '0' for apartisans as well as minor parties' identifiers. $L E A D$ is a synoptic evaluation of the main two parties' leaders based on the standard thermometer score, recoded on a scale ranging from '-1' (best score to left party's leader and worst score to right party's leader) to '1' (best score to right party's leader and worst score to left party's leader). Note that all variables are coded on the same metric, so as to allow direct comparisons of the estimates.

$<$ Table 1 about here $>$ 


\section{Preliminary analysis}

To begin with, I estimate a structurally simple cross-sectional model (i.e., all variables measured in the post-election survey) where vote choice is modeled as a function of partisanship and leader evaluations alone. Other relevant predictors of voting behavior (e.g., ideology, issue proximity, economic evaluations) are deliberately excluded from the present specification. In fact, empirical evidence shows that the exclusion of these covariates would advantage the magnitude of the partisanship coefficient - as this is generally expected to be more collinear with ideology, issues, and the economy as compared to leader evaluations (Lewis-Beck, Nadeau, and Elias, 2008). This simpler model, then, offers a tougher test of the personalization hypothesis, as it provides a rather conservative estimate of the electoral impact of leader evaluations vis-à-vis partisanship. Because vote choice has been operationalized as a nominal dependent variable, a discrete choice modeling technique such as multinomial logit is preferred to linear regression. Vote for the main leftist party stands thus as the reference category. For the sake of clarity, only the contrast between vote for the main rightist party and the reference category is shown. The various models' estimates (one model per country) are presented in Table 2.

$<$ Table 2 about here>

All coefficients are highly significant $(\mathrm{p}<.001)$ and signed as expected, and the overall fit of the models is satisfactory. These results would seem to vindicate the conventional wisdom of electoral research, in the sense that parties dominate over leaders in each and every case (albeit only slightly in the British case). However, we cannot uncritically accept these results, for as far as both the dependent variable and the main covariates 
are measured at the same point in time (i.e., after the election has taken place) the causal dynamics underlying their mutual relationship remain unclear.

In order to tackle this issue, I estimated a dynamic model that takes full advantage of the panel structure of the data. As in the previous model, the dependent variable is measured in the post-election wave of the survey, whereas the main covariates are now measured in the pre-election wave. This operational choice assures that the independent variables meet the important causal criterion of occurring prior in time. Estimation takes place once again through multinomial logistic regression. The results are presented in Table 3.

$<$ Table 3 about here $>$

Estimates from the dynamic model highlight a more balanced contribution on behalf of the two predictors of interest. Admittedly, parties still dominate over leaders in the German case. Yet their relative effect is now tantamount in the case of Italy, whereas in Britain leaders would appear to have overcame parties. Overall, this analysis reveals a strong effect on behalf of the leader variable - an effect that appears generally stronger than in previous analyses. However, not even these findings can be accepted as such, because the model specification from which they stem is unable to control for the repeatedly highlighted endogeneity between predictor variables. No safe conclusion about their relative effect on the vote can be drawn without taking into account this potential source of bias. For this reason, it is necessary to resort to instrumental variable estimation. 


\section{Exogenizing partisanship: An instrumental variable approach}

In terms of econometric theory, instrumental variables allow consistent estimation when covariates are endogenous. The procedure employed to create an instrumental variable is as follows:

In the first stage, the endogenous independent variable, $\mathrm{Y}$, is regressed on proper exogenous variables, thus creating an instrumental variable $Y^{\prime}$. In the second stage, this $Y^{\prime}$ is substituted into the original equation, and reestimation takes place. The method "works" because the instrumental variable is effectively exogenous, thereby eliminating the source of the difficulty (Lewis-Beck, Nadeau, and Elias, 2008, p. 88).

The crucial requirement for creating an instrumental variable is that the exogenous variables selected are effectively exogenous: they must be determined outside the system and not object of causal explanation in the model. In addition, each exogenous variable must be $(i)$ uncorrelated with the error term in the explanatory equation, but (ii) correlated with the endogenous variable they are instrumenting (Kennedy, 2008, chapter 9). In the case of partisanship, these standards are readily obtainable with safely exogenous socio-economic (SES) variables. For one thing, party identification itself is conceived as the result of an individual's placement within the social structure (Campbell et al., 1960). At the same time, recent analyses of voting behavior in advanced industrial democracies have shown the progressive inability of these indicators to account for individuals' vote choice (see, most notably, the various country chapters in: Franklin, Mackie, and Valen, 1992). Moreover, this interpretation would seem to fit perfectly the data at hand (explained variance in a linear probability model 
where vote is the dependent variable and all the available SES measures from our datasets are simultaneously included as covariates ranges between a mere $3.9 \%$ in the German case and a yet unsatisfactory $9.9 \%$ in the British case. Full estimation procedure is available in Appendix). In other words, our SES variables meet the necessary conditions for consistent estimation (Sovey and Green, 2010) as their effect on the outcome (i.e.., vote choice) is transmitted solely through the mediating variable (i.e., partisanship).

Our instrumental variable for partisanship - $P I D^{\prime}$ - is thus constructed from a number of SES measures available in each dataset, including: age, gender, educational level, social class ${ }^{3}$, trade union membership, type of employment, unemployment status $^{4}$, region of residence and religious denomination. The instruments are "good" as their correlation with the original partisanship variable ranges between .23 in both Germany and Italy and .29 in Britain - these values being substantially comparable to those reported by Lewis-Beck, Nadeau, and Elias (2008, p. 91) in a similar exercise. Substituting the original partisanship variable for our instrumental variable in the dynamic model yields the results presented in Table 4 .

$<$ Table 4 about here $>$

The results from the instrumental variable estimation speak clearly in favor of our expectations. Once the endogenous status of partisanship is taken into account, the effect of leader evaluations emerges more clearly. Indeed, leaders would now appear to dominate over parties in each and every case. If correctly exogenized, partisanship plays a much weaker role within voters' electoral calculus than often assumed. 


\section{Robustness checks}

To test the robustness of these findings, I have carried out several stability checks. In particular, I replicated the instrumental variable estimation on cross-sectional data (i.e., all variables measured in the post-election wave of the surveys) in order to accommodate for the possible influence on political attitudes exerted by the campaign. Results remain substantially stable: if any, the relative impact of leaders appears stronger. ${ }^{5}$ As a further check, I performed a number of jackknife tests. To evaluate the stability of the instruments, I excluded one exogenous variable at a time from the construction of each instrument, every time re-estimating the model with the new instrument. The model fit remains in every instance practically unchanged, thus assuring that the performance of the models does not rest on the presence or absence of any specific exogenous variable in the construction of the instruments.

As a final test, I estimated a slightly more complex model of voting that takes into account also the effect exerted by ideology (i.e., respondent's self-placement on the leftright scale, as measured in the pre-election wave). The inclusion of this additional control bears virtually no effect on the results. ${ }^{6}$

\section{Concluding remarks}

A pervasive phenomenon in contemporary democracies, the personalization of politics has been the subject of considerable attention by political scientists. Against the conventional wisdom that sees party leaders as a fundamental electoral asset for their parties, however, previous empirical literature have seldom recognized the importance of leader evaluations in the individual voting calculus. In line with traditional interpretations of voting behavior, earlier studies have habitually explained short-term forces such as party leader images in terms of the (assumed) causally prior strength of 
party identifications. However, the validity of this interpretation of the vote depends heavily on the effectively exogenous status of party identification. A number of recent studies demonstrates that partisanship and leader evaluations are indeed tight by a link of reciprocal causation. In such context, single-equation models of voting are likely to provide seriously biased estimates. To overcome this problem, I employed a classic econometric remedy: instrumental variable estimation. The results show that once endogeneity is taken into account (and proper data sources are employed) the electoral effect of leader evaluations appears much stronger than often observed.

A note of caution is in order here. Although belonging to the parliamentary typology, the three countries analyzed in this paper (Britain, Germany, and Italy) might represent a rather favorable testing ground for the personalization hypothesis as compared with, e.g., the Scandinavian countries (cf. Barisione, 2009). Moreover, the choice to limit the analysis to the two main parties in each country implies the possibility of amplifying to some extent the electoral effect of a party leader that is also a candidate to the premiership. In this sense, much more research on a wider span of countries and parties is in order. The modest hope of this paper is that of having provided an alternative (and hopefully more sound) way to look at leader effects for those who will answer to this call for further research. 


\section{Endnotes}

${ }^{1}$ For a better discussion of this point, see: Garzia and De Angelis, 2011.

2 These datasets have been selected on the basis of two criteria, namely design (i.e., pre/post-election panel survey) and timeliness (i.e., the most recent from each country featuring the panel design).

${ }^{3}$ Not available in the German dataset.

${ }^{4}$ In the British case, this is substituted for annual household income.

5 Post/post estimation with instrumental variables:

Britain: PID' = 2.49; LEAD = 7.92

Germany: PID' = 2.32; LEAD $=5.10$

Italy: PID' $=2.76 ;$ LEAD $=6.20$

${ }^{6}$ Pre/post estimation with instrumental variables, controlling for ideology:

Britain: PID' = 2.47; LEAD = 5.06

Germany: PID' $=2.27 ;$ LEAD $=4.32$

Italy: PID' $=3.32 ;$ LEAD $=4.55$ 


\section{References list}

Aarts, K., Blais, A., and Schmitt, H. (eds.) (2011) Political Leaders and Democratic Elections, Oxford: Oxford University Press.

Asher, K. (1987) 'A Simultaneous Equation Model of Canadian Voting Behaviour', Canadian Journal of Political Science 20 (3), pp. 553-72.

Barisione, M. (2009) 'So, What Difference Do Leaders Make? Candidates' Images and the "Conditionality" of Leader Effects on Voting', Journal of Elections, Public Opinion and Parties 19 (4), pp. 473-500.

Brettschneider, F., and Gabriel, O. (2002) 'The Nonpersonalization of Voting Behaviour in Germany', in A. King (ed.), Leaders' personalities and the outcomes of democratic elections. Oxford: Oxford University Press, pp. 127-57.

Campbell, A., Converse, P., Miller, W., and Stokes, D. (1960) The American Voter, Chicago and London: The University of Chicago Press.

Crewe, I., and King, A. (1994) 'Did Major win? Did Kinnock lose? Leadership effects in the 1992 election', in A. Heath, R. Jowell and J. Curtice (eds.), Labour's Last Chance? The 1992 Election and Beyond. Aldershot: Dartmouth, pp. 125-47.

Curtice, J., and Holmerg, S. (2005) 'Party leaders and party choice', in J. Thomassen (ed.), The European Voter. Oxford: Oxford University Press, pp. 235-53.

Dinas, E. (2008) 'Big expectations, small outcomes: The impact of leaders' personal appeal in the 2004 Greek election', Electoral Studies 27 (4), pp. 505-17.

Evans, G., and Andersen, R. (2005) 'The impact of party leaders: how Blair lost Labour votes', Parliamentary Affairs 58 (4), pp. 818-36.

Farrell, D., and Webb, P. (2000) 'Political Parties as Campaign Organizations', in R. Dalton and M. Wattenberg (eds.), Parties without Partisans. Political Change in Advanced Industrial Democracies. Oxford: Oxford University Press, pp. 102-28.

Franklin, M., Mackie, T., and Valen, H. (eds.) (1992) Electoral change: Responses to evolving social and attitudinal structures in Western countries, Cambridge: Cambridge University Press. 
Garzia, D. (2011) 'The Personalization of Politics in Western Democracies: Causes and Consequences on Leader-Follower Relationships', The Leadership Quarterly 22 (4), pp. 697-709.

Garzia, D. (2012) 'Changing Parties, Changing Partisans. The Personalization of Partisan Attachments in Western Europe', Political Psychology, article in press.

Garzia, D., and De Angelis, A. (2011) 'Partisanship, Leader Evaluations, and the Vote: Breaking the New Iron Triangle in Electoral Research'. Paper presented at the $1^{\text {st }}$ European Conference on Comparative Electoral Research, Sofia, 1-3 December.

Hayes, B., and McAllister, I. (1997) 'Gender, Party Leaders, and Election Outcomes in Australia, Britain, and the United States', Comparative Political Studies 30 (1), pp. $3-26$.

Holmberg, S. (2007) 'Partisanship reconsidered', in R. Dalton and H. Klingemann (eds.), The Oxford Handbook of Political Behavior. Oxford: Oxford University Press, pp. 557-70.

Holmberg, S., and Oscarsson, H. (2011) 'Party Leader Effects on the Vote', in K. Aarts, A. Blais and H. Schmitt (eds.), Political Leaders and Democratic Elections. Oxford: Oxford University Press, pp. 35-51.

Johnston, R. (2006) 'Party Identification: Unmoved Mover or Sum of Preferences?', Annual Review of Political Science 9, pp. 329-51.

Karvonen, L. (2010) The personalisation of politics. A study of parliamentary democracies, Colchester: ECPR Press.

Kennedy, P. (2008) A Guide to Econometrics, 6 ${ }^{\text {th }}$ Edition, Malden, MA: Blackwell Publishing.

King, A. (ed.) (2002) Leaders' Personalities and the Outcomes of Democratic Elections, Oxford: Oxford University Press.

Lewis-Beck, M., Nadeau, R., and Elias, A. (2008) 'Economics, Party, and the Vote: Causality Issues and Panel Data', American Journal of Political Science 52 (1), pp. 84-95.

Mair, P., Muller, W., and Plasser, F. (eds.) (2004) Political parties and electoral change: party responses to electoral markets, London: Sage. 
Manin, B. (1997) The principles of representative government, Cambridge: Cambridge University Press.

Marks, G. (1993) 'Partisanship and the Vote in Australia: Changes over Time 19671990', Political Behavior 15 (2), pp. 137-166.

McAllister, I. (2007) 'The Personalization of Politics', in R. Dalton and H. Klingemann (eds.), The Oxford Handbook of Political Behavior. Oxford: Oxford University Press, pp. 571-88.

Miller, W., and Shanks, M. (1996) The new American voter, Cambridge: Harvard University Press.

Mughan, A. (2000) Media and the Presidentialization of Parliamentary Elections, London: Palgrave.

Page, B., and Jones, C. (1979) 'Reciprocal effects of policy preferences, party loyalties and the vote', American Political Science Review 73 (4), pp. 1071-90.

Sovey, A., and Green, D. (2010) 'Instrumental Variables Estimation in Political Science: A Readers' Guide', American Journal of Political Science 55 (1), pp. 188-200.

Thomassen, J. (ed.) (2005) The European Voter, Oxford: Oxford University Press. 
Table 1. Coding of the dependent variable

\begin{tabular}{ccc}
\hline$(-1)$ & $(0)$ & $(1)$ \\
\hline Vote for Main Leftist-Party & & Vote for Main Rightist-Party \\
Labour (Britain) & Vote for other parties & Conservatives (Britain) \\
SPD (Germany) & Abstention & CDU/CSU (Germany) \\
Left Democrats (Italy) & & Forza Italia (Italy) \\
\hline
\end{tabular}


Table 2. Cross-sectional analysis

\begin{tabular}{lccc}
\hline & Britain & Germany & Italy \\
\hline PID (Post) & $4.85(.26)^{*}$ & $4.23(.13)^{*}$ & $6.88(.35)^{*}$ \\
LEAD (Post) & $4.75(.43)^{*}$ & $3.09(.25)^{*}$ & $3.90(.42)^{*}$ \\
Pseudo-R ${ }^{2}$ & .70 & .52 & .71 \\
$\mathrm{~N}$ & 1457 & 4006 & 1264 \\
\hline
\end{tabular}

Note: Multinomial logit estimates. Standard error in parentheses. ${ }^{*} p<.001$ 
Table 3. Pre/post estimation

\begin{tabular}{lccc}
\hline & Britain & Germany & Italy \\
\hline PID (Pre) & $3.00(.19)^{*}$ & $3.67(.12)^{*}$ & $3.40(.29)^{*}$ \\
LEAD (Pre) & $4.12(.35)^{*}$ & $2.79(.24)^{*}$ & $3.61(.34)^{*}$ \\
Pseudo-R & .57 & .45 & .47 \\
$\mathrm{~N}$ & 1414 & 3951 & 1210 \\
\hline
\end{tabular}

Note: Multinomial logit estimates. Standard error in parentheses. ${ }^{*} p<.001$ 
Table 4. Pre/post estimation with instrumental variables

\begin{tabular}{lccc}
\hline & Britain & Germany & Italy \\
\hline PID'(Pre) & $3.70(.49)^{*}$ & $2.60(.34)^{*}$ & $3.88(1.08)^{*}$ \\
LEAD (Pre) & $6.02(.36)^{*}$ & $4.67(.22)^{*}$ & $5.05(.32)^{*}$ \\
Corr. PID - PID' & .29 & .23 & .23 \\
Pseudo-R ${ }^{2}$ & .46 & .21 & .39 \\
$\mathrm{~N}$ & 1137 & 3850 & 1204 \\
\hline
\end{tabular}

Note: Multinomial logit estimates. Standard error in parentheses. ${ }^{*} p<.001$ 
APPENDIX. Socio-economic status (SES) and vote choice

\begin{tabular}{|c|c|c|c|}
\hline & Britain, 2010 & Germany, 2009 & Italy, 2006 \\
\hline \multicolumn{4}{|l|}{ Socio-demographics } \\
\hline Age & .00 & .00 & -.00 \\
\hline Gender & -.01 & .01 & -.02 \\
\hline Education & -.01 & -.02 & -.02 \\
\hline \multicolumn{4}{|l|}{ Social class } \\
\hline Middle class & $.14^{*}$ & - & .01 \\
\hline Union member & $-.19 * *$ & $-.21^{* *}$ & $-.15^{* *}$ \\
\hline Unemployed & - & .07 & .03 \\
\hline Annual Income & $.02^{* *}$ & - & - \\
\hline \multicolumn{4}{|l|}{ Professional sector } \\
\hline Private & .15 & - & - \\
\hline Public & .04 & - & - \\
\hline \multicolumn{4}{|l|}{ Type of work } \\
\hline Manual & - & .05 & - \\
\hline White collar & - & $.09^{*}$ & - \\
\hline Civil servant & - & $.17^{* *}$ & - \\
\hline Farmer & - & .38 & - \\
\hline Self-employed & .36 & $.13^{*}$ & - \\
\hline Employee & - & - & $-.10 *$ \\
\hline Atypical & - & - & $-.22^{* *}$ \\
\hline \multicolumn{4}{|l|}{ Religion } \\
\hline Catholic & -.41 & .25 & $.33^{*}$ \\
\hline Church of England & -.21 & - & - \\
\hline Protestant & - & .09 & - \\
\hline Other & -.36 & .05 & .32 \\
\hline No religion & -.32 & .02 & .01 \\
\hline \multicolumn{4}{|l|}{ Region } \\
\hline Scotland & $-.16^{*}$ & - & - \\
\hline Wales & -.10 & - & - \\
\hline East/West & - & $.13^{* *}$ & - \\
\hline North-West & - & - & .07 \\
\hline North-East & - & & .04 \\
\hline Centre & - & - & $-.18^{*}$ \\
\hline Adjusted R-squared & .099 & .035 & .062 \\
\hline $\mathrm{N}$ & 1193 & 3924 & 1371 \\
\hline
\end{tabular}

Note: Multiple regression estimates (OLS). Dependent variable: Vote. ${ }^{* *} \mathrm{p}<.01{ }^{*} \mathrm{p}<.05$ 